\title{
Surrogacy reform and its impact on the child's right to birth registration
}

\author{
Elaine O'Callaghan
}

\author{
School of Law, University College Cork, Ireland
}

\begin{abstract}
The regulation and reform of surrogacy law will inevitably have an impact on the system of birth registration and the content of birth certificates. This Commentary considers deliberations around reform in Ireland, the UK and Australia, where different approaches have been adopted. In Ireland, for example, a surrogacy certificate has been proposed that will not reference the fact that the child was born as a result of surrogacy. Meanwhile, in the UK, it is proposed that the full birth certificate will record that it was a surrogate birth but will not record the identity of the surrogate. In Australia, a review of the role of states and territories regulating surrogacy has emphasized that not enough information is being recorded on birth certificates to safeguard children's rights. I conclude that it is time to assess the purpose of a birth certificate and consider its role in realizing the child's rights to birth registration and to identity under international human rights law.

(c) 2021 The Author(s). Published by Elsevier Ltd. This is an open access article under the CC BY-NC-ND license (http://creativecommons.org/ licenses/by-nc-nd/4.0/).
\end{abstract}

KEYWORDS: birth registration, children's rights, law commission, regulation, reform, surrogacy

\section{Introduction}

The legal framework in respect of surrogacy is under review in a number of jurisdictions, including Ireland (General Scheme of the Assisted Human Reproduction Bill; Department of Health, 2017), the UK (Building Families Through Surrogacy: A New Law. A Joint Consultation Paper; Law Commission of England and Wales and Scottish Law Commission, 2019) and Australia (Surrogacy Matters: Inquiry into the Regulatory and Legislative Aspects of International and Domestic Surrogacy Arrangements; House of Representatives Standing Committee on Social Policy and Legal Affairs, 2016). Consideration of how to recognize the child's intended parents, the surrogate and any gamete donors, where relevant, forms an important part of this. Analysis to date has demonstrated that birth registration

E-mail address: elaineocallaghan@ucc.ie and subsequent birth certificates require particular attention. Indeed, wider reform of the birth registration system in itself has frequently been discussed (Crawshaw et al., 2017; McCandless, 2017; Higgs, 2018), as has specific reform in respect to transgender parents (Margaria, 2020; SlothNielsen and SlothNielsen, 2020).

This commentary considers the impact that surrogacy reform will have on birth registration from a children's rights perspective. Part I of this commentary examines how surrogacy is recorded on birth certificates and presents a glimpse of the challenges for reform. Part II outlines the child's right to birth registration and to identity under international human rights law. Part III considers what content could be recorded on a birth certificate. Part IV sets out the conclusions. In particular, it is argued that it is time to take stock of the purpose of a birth certificate and to assess its value to children in realizing their rights to birth registration and to identity under international human rights law. 


\section{Recording surrogacy: birth registration and birth certificates}

Registering the birth of a surrogate born child raises a number of questions for States regarding the recognition of parentage and of the surrogacy in itself. The approach taken by States can depend on whether surrogacy is regulated or unregulated. A study by the Hague Conference on Private International Law (2014, [28]) details that States which do not regulate surrogacy generally do not record that the birth was a surrogate birth on the birth certificate. Instead, the usual legal parentage rules apply, and this often involves the intended mother adopting the child. In those circumstances, the child is issued an adoption certificate. Meanwhile, in States that regulate surrogacy, the study by the Hague Conference specifics that the child will generally be issued a new birth certificate following the transfer of legal parentage from the surrogate to the intended parents. Again, reference is not made to the surrogate or the surrogacy on the new certificate; instead, this is held on State records. Furthermore, some States register the intended parents as the legal parents from birth, with no reference to the surrogate. The implications of this, and whether States are required to recognize and register such birth certificates, was extensively discussed by the European Court of Human Rights (ECtHR) in Mennesson v. France (Application no. 65192/11, 2014) and in an Advisory Opinion by the Grand Chamber of the ECtHR (Request no. P16-2018001, 2019).

In Ireland, surrogacy is currently unregulated. Head 36 of the General Scheme of the Assisted Human Reproduction Bill 2017 ('the AHR Bill 2017') proposes to facilitate domestic, gestational and altruistic surrogacy. Proposals for reform are based on a post-birth transfer of parentage from the surrogate to the intended parents. Head 51 of the AHR Bill 2017 links the Register of births with the proposed new National Surrogacy Register and the courts, making it possible for surrogacy certificates to be issued, which would have the same legal standing as birth certificates. In essence, this means that the surrogate will be recorded as the birth mother in the register of births, and a separate, 'surrogacy certificate' will subsequently be issued that will outline the 'details of the parents declared on the Parental Order', as provided for in Head 52(4) of the AHR Bill 2017. According to the Explanatory Note to Head 52 of the AHR Bill 2017, the 'details entered in the register of births, naming the surrogate as the mother of any child born to her under a surrogacy agreement will not be subsequently amended solely because the court grants a Parental Order declaring the intending parent(s) to be the legal parent(s) of the child'. Details of the surrogacy will be held on State records, available to the child at the age of 18 years.

The Law Commission of England and Wales and the Scottish Law Commission (2019) ('the Law Commissions') have put forward proposals regarding the reform of surrogacy in the UK. This includes a 'new pathway' recognizing intended parents as 'the parents' on the child's birth certificate. In making this proposal, the Law Commissions (2019, p. 244) have stated that 'the full (not short) birth certificate of the child should note that he or she was born as a result of a surrogacy arrangement (without providing information as to the identity of the surrogate; this information would instead be recorded on the register). The Law Commissions (2019, p. 245) have also sought views as to whether a wider reform of birth registration is necessary, including the possibility of facilitating more than two parents to be recorded on the birth certificate.

It is striking to note that two quite different approaches have been proposed in Ireland and in the UK. It is evident, as McCandless (2017, p. 56) has suggested, that any law reform must first clarify the purpose of birth registration and that this purpose may differ now from what was originally intended in the 1800 s. While jurisdictions will inevitably have different perspectives regarding birth registration, this author contends that it is important that jurisdictions consider the traumatic experience of those who have been deprived access to their birth certificate, or those who have been given forged birth certificates. In Ireland, for example, a painful history involving serious revelations about illegal birth registrations, coupled with the recent publication of the Final Report of the Commission of Investigation into Mother and Baby Homes, in January, 2021, has further emboldened the importance of access to information about origins, identity and birth certificates (Department of Children, Equality, Disability, Integration and Youth, 2017)). Indeed, the Irish Government has been under political pressure to expedite publication of the Adoption (Information and Tracing) Bill, to facilitate access to birth certificates, and this is due to be published in 2021. Mulligan (2020, p. 41) adeptly captured the impact of 'the Irish experience in terms of failing to respect biological kinship' and commented that this 'may well underpin the normative position that a surrogate-born person is wronged if deprived of the knowledge that he or she is surrogate born, and of the opportunity to contact that surrogate'. It is submitted here, that Irish history in respect to birth registration in adoption has reinforced the importance of birth certificates, and this should be instructive for other jurisdictions. Furthermore, the experience in the UK where 'anecdotally it is known that at least some commissioning parents illegally registered themselves as the child's parents' in surrogacy arrangements (Blyth, 2010, p. 345), as well as in Australia in respect to forced adoption, and its impact on birth certificates (Commonwealth Contribution to Former Forced Adoption Policies and Practices; pp. 249-252) must also be considered.

Proposals for reform in the UK and Ireland share commonalities, however, in that both jurisdictions propose establishing a national register of surrogacy arrangements. This is an important development from a children's rights perspective and is in line with recommendations from the UN Special Rapporteur on the sale and sexual exploitation of children, including child prostitution, child pornography and other child sexual abuse material, that such records regarding children's genetic and gestational origins should be kept (United Nations 2019, A/74/162: 20 [101(d)]).

\section{The right to birth registration (and to a birth certificate?)}

Higgs (2018, p. 36) has explained the historical emergence of birth certificates in England and Wales since 1836 and 
their initial focus on property rights and inheritance. Birth registration followed in Scotland in 1855 and in Ireland in 1864 (The National Archives, n.d.). Since then, international human rights law has ascribed birth registration as a right of the child. The right to birth registration is provided for in Article 24(2) of the International Covenant on Civil and Political Rights and Article 7(1) of the UN Convention on the Rights of the Child (CRC). Tobin and Seow (2019, p. 239), describing the 'enabling role' of Article 7, comment that 'when combined with the right to a name, the registration of a child's birth provides a child with legal recognition of their existence, which is fundamental if a child is able to effectively claim and enjoy all his or her rights under the Convention'.

However, as SlothNielsen and SlothNielsen (2020, p. 212) explain, 'Less clear is whether the right to birth registration includes the right to a birth certificate.' This is a significant question, particularly when considering the interconnected question as to 'whose birth certificate is it? The state's, the parent's or the child's?' (SlothNielsen and SlothNielsen, 2020 , p. 212). The investment of all three parties in birth certificates is evident when considering the procedural process involved in birth registration, as described by the UN High Commissioner for Human Rights (Human Rights Council, 2014, [5]): 'First, there must be the declaration of the occurrence of the birth to civil registrars. Second, once notified, civil registrars officially record the birth ... Third, the State issues a birth certificate, a personal document to attest birth registration and the most visible evidence of the State's legal recognition of the child.' The description of a birth certificate as a 'personal document' is important, and suggests the child's rights in respect of this state record. Gerber et al. (2011, p. 435) have argued that 'a right to a birth certificate is an implicit part of the right to birth registration'. Indeed, Gerber et al. (2011, p. 435) state that a birth certificate 'provides the substance to the right to birth registration'. While this conclusion is reasonable, the authors have called on the Human Rights Committee and the Committee on the Rights of the Child to 'clearly articulate, with coherent legal analysis, the precise content of the right to birth registration by way of a General Comment' (2011, p. 436). This is supported here, and I further contend that a particular emphasis on the impact of donor-assisted human reproduction, including surrogacy, should form part of this. Clarity from international human rights committees is necessary given the evident challenges faced by States regarding birth registration in the context of surrogacy law reform. The different proposals that are currently advanced in both the UK and Ireland suggest that these jurisdictions are unclear as to what their international obligations require from a children's rights perspective.

Article 8 of the CRC provides for the child's right to identity. According to Tobin (2019, p. 282), this Article 'and the concept of the child's right to an identity establish in unqualified terms that children are subjects under law whose separate legal identities must be preserved and whose rights under the Convention must be assured'. SlothNielsen and SlothNielsen (2020, p. 212) have commented that 'The right to identity and the right to birth registration are linked, but not equivalent. The right to identity builds on the right to birth registration.' Internationally, many jurisdictions limit the number of parents who can be recorded on a birth certificate. Some jurisdictions, however, including Ontario and British Columbia, facilitate up to four or five parents to be registered on a birth certificate (Gerber and Lindner, 2015, p. 43; Ontario: Children's Law Reform Act, R.S.O. 1990, c. C. 12). Interestingly, Higgs (2018, p. 36) has explained that it was not uncommon for children to have three or four parents in early-modern times, as godparents played an important role in their lives.

\section{Content of a birth certificate}

There has been considerable discussion since the publication of the Warnock Report as to what information should be recorded on birth certificates. The need for reform has been proposed for several reasons including a 'lack of parental disclosure' to children about their origins, the 'State's collusion in deception' of donor-conceived children, and the fact that some donor-conceived people, as well as their parents, are in favour of reforming birth certificates (Blyth et al., 2009, pp. 216-218).

Crawshaw et al. (2017, p. 2) are critical of the failure of the birth registration system in the UK to record details of gamete donors and more than two parents in 'multiparenting arrangements' in the context of children's identity rights. Furthermore, in Australia, the House of Representatives Standing Committee on Social Policy and Legal Affairs (2016) has recommended that the Australian Law Reform Commission 'should consider whether a child's birth certificate should contain information on all gestational, genetic and intended parents, including a record that the child was born as a result of a surrogacy arrangement' (p. 20). In response to this recommendation, the Australian government stated that it 'would raise ... the specific issue of information recorded on birth certificates ... as part of its engagement with states and territories through CAG' (Australian Government response to the Standing Committee on Social Policy and Legal Affairs report: Surrogacy Matters, 2018, p. 5). This recommendation follows numerous submissions to the House of Representatives Standing Committee which noted that birth certificates 'may not contain sufficiently detailed information for the child to later establish information on both their birth and genetic heritage' (House of Representatives Standing Committee on Social Policy and Legal Affairs, 2016, p. 19). Principle 9 of the 'International Principles for Donor Conception and Surrogacy', which are 'informed by the lived experience of the drafters as donorconceived' people, calls for birth registration to record that 'the child is donor-conceived and/or surrogacy-born' (Change.org, n.d.). Furthermore, Principle 10 states that 'All donor-conceived and surrogacy-born people have the right to be notified of their status.' This mirrors Wade's calls for 'mandatory disclosure ... in cases of surrogacy and/or gamete donation' that 'could involve birth certificate annotations which inform people that additional information is available about the manner of their birth' (2020, pp. 748749). 


\section{Conclusions}

Surrogacy reform, and its impact on birth registration and birth certificates, must be considered from a children's rights perspective. Failure to do so will inevitably result in disputes before the courts, as is evident in respect to transgender parents, and calls for law reform (Gerber and Lindner, 2015; McCandless, 2017; Margaria, 2020; SlothNielsen and SlothNielsen, 2020). It is time to take stock of the purpose of a birth certificate and to assess whether it can facilitate children to adequately enjoy their rights under the CRC. The views of surrogate-born children, as well as of surrogates, intended parents and gamete donors should be ascertained as part of any reform in this area. It is suggested here that any reform of birth certificates in respect to surrogacy must also consider birth certificates in respect to donor conception that currently do not reference the involvement of a third party. This is important to ensure parity in the consideration of children's rights law, including issues around privacy. The call for a General Comment detailing the right to birth registration is supported here, with a particular emphasis on the impact of donorassisted human reproduction, including surrogacy. The need for this is clear given the ongoing deliberations which States are having concerning birth registration and the uncertainty regarding the extent of international obligations in respect to children's rights.

\section{Acknowledgement}

The author would like to thank the anonymous reviewers for valuable comments on an earlier draft of this piece.

\section{References}

Australian Government response to the Standing Committee on Social Policy and Legal Affairs report: Surrogacy Matters (November, 2018) Australian Government response to the Surrogacy Matters report (ag.gov.au) (accessed 07.04.2021)

Blyth, E., 2010. Parental Orders and identity registration: one country three systems. J. Social Welfare Family Law 32, 345352. https: //doi.org/10.1080/09649069.2010.539353.

Blyth, E., Frith, L., Jones, C., Spiers, J.M., 2009. The role of birth certificates in relation to access to biographical and genetic history in donor conception. Int. J. Children's Rights 17 (2), 207-234. https://doi.org/10.1163/157181808X389254.

Change.org. International Principles for Donor Conception and Surrogacy Petition - Making Humans: International Principles for Donor Conception and Surrogacy . Change.org, n.d. (accessed 07.04.2021).

Crawshaw, M.A., Blyth, E.D., Feast, J., 2017. Can the UK's birth registration system better serve the interests of those born following collaborative assisted reproduction? Reprod. BioMed. Soc. 4, 1-4. https://doi.org/10.1016/j.rbms.2016.12.004.

Department of Children, Equality, Disability, Integration and Youth. Final Report of the Commission of Investigation into Mother and Baby Homes (January, 2021) gov.ie - Final Report of the Commission of Investigation into Mother and Baby Homes (www.gov.ie) (accessed 07.04.2021).

European Court of Human Rights, Grand Chamber. Advisory Opinion concerning the recognition in domestic law of a legal parentchild relationship between a child born through a gestational surrogacy arrangement abroad and the intended mother,
Requested by the French Court of Cassation (Request no. P162018-001), 10 April, 2019. Advisory opinion concerning the recognition in domestic law of a legal parent-child relationship between a child born through a gestational surrogacy arrangement abroad and the intended mother (coe.int) (accessed 07.04.2021).

General Scheme of the Assisted Human Reproduction Bill 2017 (Department of Health, 2017). gov.ie - General Scheme of the Assisted Human Reproduction Bill 2017 (www.gov.ie) (accessed 07.04.2021).

Gerber, P., Gargett, A., Castan, M., 2011. Does the right to birth registration include a right to a birth certificate. Netherlands Quart. Human Rights 29 (4), 434-459. https://doi.org/10.1177/ 016934411102900403.

Gerber, P., Lindner, P., 2015. Modern Families: Should Children Be Able to Have More than Two Parents Recorded on Their Birth Certificates. 5 Victoria University Law Justice J. 5, 34-48, https://doi.org/10.15209/vulj.v5i1.

Hague Conference on Private International Law, A study of legal parentage and the issues arising from international surrogacy arrangements, Prel. Doc. No 3C (March, 2014). bb90cfd2-a66a4fe4-a05b-55f33b009cfc.pdf (hcch.net) (accessed 05.02.2021).

Higgs, E., 2018. UK birth registration and its present discontents. Reprod. BioMed. Soc. 5, 35-37. https://doi.org/10.1016/j. rbms.2017.11.001.

House of Representatives Standing Committee on Social Policy and Legal Affairs, Parliament of Australia, Surrogacy Matters: Inquiry into the regulatory and legislative aspects of international and domestic surrogacy arrangements (2016). Report - Parliament of Australia (aph.gov.au) (accessed 07.04.2021).

Human Rights Council, Birth registration and the right of everyone to recognition everywhere as a person before the law, Report of the Office of the United Nations High Commissioner for Human Rights, A/HRC/27/22, (17 June 2014). Refworld | Birth registration and the right of everyone to recognition everywhere as a person before the law: Report of the Office of the United Nations High Commissioner for Human Rights (accessed 07.04.2021).

Law Commission of England and Wales and Scottish Law Commission, Building families through surrogacy: a new law. A joint consultation paper, (06 June, 2019). Surrogacy I Law Commission (accessed 07.04.2021).

Margaria, A., 2020. Trans men giving birth and reflections on fatherhood: what to expect? Int. J. Law, Policy Family 34, 225246. https://doi.org/10.1093/lawfam/ebaa007.

McCandless, J., 2017. Reforming birth registration law in England and Wales? Reprod. BioMed. Soc. 4, 52-58. https://doi.org/ 10.1016/j.rbms.2017.07.001.

Mennesson v. France, Application no. 65192/11, (26 June, 2014) MENNESSON v. FRANCE [Extracts] (coe.int) (accessed 07.04.2021).

Mulligan, A., 2020. Protecting identity in collaborative assisted reproduction: the right to know one's gestational surrogate. Int. J. Law, Policy Family 34, 20-42. https://doi.org/10.1093/ lawfam/ebz017.

National Archives, The. Births, marriages and deaths in Scotland and Ireland - The National Archives, n.d. (accessed 07.04. 2021).

SlothNielsen, J., SlothNielsen, R., 2020. Mothers and others: transgender birth, birth registration and the rights of the child, with a focus on the United Kingdom and South Africa. Int. J. Discrimination Law 20, 203-223. https://doi.org/10.1177/ 1358229120970142.

The Senate Community Affairs References Committee, Commonwealth Contribution to Former Forced Adoption Policies and Practices, Commonwealth of Australia, 2012. https://www. aph.gov.au/About_Parliament/Senate/Whats_On/Commonwealth_contribution_to_former_forced_adoption_policies_and_ practices. 
Tobin, J., 2019. The right to preservation of a child's identity. In: Tobin, J. (Ed.), The UN Convention on the Rights of the Child: A Commentary. Oxford University Press, pp. 281-306. https:// doi.org/10.1093/law/9780198262657.001.0001.

Tobin, J., Seow, F., 2019. The right to birth registration, a name, nationality, and to know and be cared for by parents. In: In Tobin, J. (Ed.), The UN Convention on the Rights of the Child: A Commentary. Oxford University Press, pp. 237-280. https:// doi.org/10.1093/law/9780198262657.001.0001.

United Nations. Report of the UN Special Rapporteur on the sale and sexual exploitation of children, including child prostitution, child pornography and other child sexual abuse material, Safeguards on the protection of the rights of the children born from surrogacy arrangements A/74/162 (15 July 2019) OHCHR । Annual reports (accessed 07.04.2021).

Declaration: The author reports no financial or commercial conflicts of interest.

Received 5 February 2021; refereed 14 April 2021; accepted 1 June 2021. 